\title{
Development of land-cover spatial database using satellite imagery: lesson learned from southern part of Sumatera
}

Irvan Ananda, Assyria Umela, Nila Ratnasari, Desi Putri, Yuniarsita Wulandari, et al.

Irvan N. Ananda, Assyria F. Umela, Nila Ratnasari, Desi A. Putri, Yuniarsita S. Wulandari, Projo Danoedoro, "Development of land-cover spatial database using satellite imagery: lesson learned from southern part of Sumatera," Proc. SPIE 11311, Sixth Geoinformation Science Symposium, 113110V (21 November 2019); doi: 10.1117/12.2548890

Event: Sixth Geoinformation Science Symposium, 2019, Yogyakarta, Indonesia 


\title{
Development of Land-cover Spatial Database using Satellite Imagery: Lesson Learned from Southern Part of Sumatera
}

\author{
Irvan N. Ananda ${ }^{1 \mathrm{a}}$, Assyria F. Umela ${ }^{2 \mathrm{ab}}$, Nila Ratnasari ${ }^{3 a}$, Desi A. Putri ${ }^{4 a}$, Yuniarsita S. Wulandari ${ }^{5 a}$, \\ Projo Danoedoro ${ }^{6 a}$
}

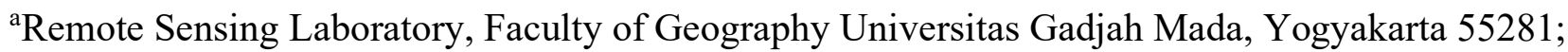

${ }^{\mathrm{b}}$ Remote Sensing MSc Program, Faculty of Geography Universitas Gadjah Mada Yogyakarta 55281

\begin{abstract}
Development of spatial databases for systematic thematic mapping is a complex activity, as compared to mapping a small area with arbitrary boundaries. This research was conducted in the provinces of Riau Islands, Bangka Belitung Islands, Jambi, and Bengkulu, southern Sumatera. The stages of spatial databases development involved remote sensing, GIS, and cartographic activities. A synoptic overview of the landscape was carried out prior to the spatial database development. The landscape complexity was assessed using landscape-ecological approach, which was implemented in the delineation and classification. The remote sensing process started from spatial data collection of various images with various spatial resolutions, image pre-processing, followed by image analysis and interpretation. Pan-sharpened Landsat8 images (15 meters) were used as main data, supported by SPOT 6/7 imagery (6 meters), Sentinel-2A imagery (10 meters) and DEMNAS digital elevation model (8 meters) for particular areas. This stage gave consequences to the multiscale analysis in the process of land-cover delineation. The GIS process comprised the stages of compiling the interpretation results to form a seamless mosaic, topology construction, coding into Indonesian Geographic Element Catalog (KUGI) standard, metadata development, followed by topology checking. Those processes aimed to achieve a single map of Sumatera at 1: 50,000 scale. The cartographic layout design was the final stage of the spatial database development, where the land-cover classes symbol was also carried out in accordance with the established standards. Some problems and solutions in the whole processes were also discussed in this paper.
\end{abstract}

Keywords: land-cover database, image interpretation, Sumatera, database development, remote sensing, GIS, cartography

\section{INTRODUCTION}

Law Number 4 in 2011 about Geospatial Information is the legal law basis for the development of geospatial information. The issuance of this law involves various stakeholders, both from the ministries/institutions and the private sector, which organize or used geospatial information data for sectoral and general purposes. Geospatial Information Agency (BIG) is a government agency that provides thematic geospatial data and information. One of the thematic data and information is the land cover map at a scale of 1: 50.000. The land cover is very dynamic objects, it can be changed each year, so it needs to be an updated land cover map. The land cover classes are one of the spatial data and information needs in regional development planning.

Land cover data and information, among others, are needed in spatial planning to create a safe, comfortable, productive, and sustainable national territory as written in Article 3 of Law Number 26 in 2007 about spatial planning. At this stage land cover data and information are needed in the preparation of zoning regulations. Furthermore, land cover data and information also have a function for monitoring the aspects of spatial use control to determine the suitability and the implementation of spatial planning. This spatial planning also supports development in rural and national strategic areas.

\footnotetext{
${ }^{1}$ ananda.irvankpj08@gmail.com

2 afumela@gmail.com

${ }^{3}$ nilaratnasari0@gmail.com

${ }^{4}$ desiariskaputri06@gmail.com

5 yuniarsitasw@gmail.com

6 projo.danoedoro@geo.ugm.ac.id
}

Sixth Geoinformation Science Symposium, edited by Sandy Budi Wibowo, Andi B. Rimba

Stuart Phinn, Ammar A. Aziz, Proc. of SPIE, Vol. 11311, 113110V · C 2019 SPIE

CCC code: 0277-786X/19/\$21 - doi: 10.1117/12.2548890 
The development of spatial databases for land cover is generally divided into several section, starting from image preprocessing, image processing, visual interpretation/delineation, field pre/survey, KUGI standard preparation, metadata and layout of thematic maps [1,2]. The standard of land cover categorization refers to the Indonesian National Standard (SNI) 7645-1 of 2014. Quality controls are carried out by the supervisor team to achieve the desired results. In each interpretation process, landscape ecological approaches are used to identify land cover classes that are related to the characteristics of the land. Interpreters often encounter several problems in the process, so that a solution is needed to become the future learning in the developing of spatial databases for land cover. This study aimed to be a solution to the problems in the development of land-cover spatial database.

\section{MATERIALS AND METHODS}

Mapping of land cover to developing spatial databases located in the provinces of Riau Islands, Bangka Belitung Islands, Jambi, and Bengkulu. The mapping process involved 34 interpreters with a total number of map sheet numbers (NLP) of 247 (red square in Figure 1). The visual interpretation of land cover classes was conducted in synoptic overview with landscape ecological approaches using Landsat-8 level $1 \mathrm{~T}$ imagery as reference data and supported by SPOT 6/7 and Sentinel-2A imagery (specifically for Riau Islands province). The Indonesian Topographic (RBI) map at scale of 1: 50.000 as the basis was used for geometric correction, while the non-optical imagery: the National Digital Elevation Model (DEMNAS) was useful in providing information on the height of the land cover class attributes. Other secondary data were Geological Map at a scale of 1: 250.000, Land System map at scale of 1: 250.000, and regional commodity map (shown in Table 1).

Table 1. Spatial data collection

\begin{tabular}{|c|c|c|c|c|c|}
\hline No. & Imagery and Maps & $\begin{array}{l}\text { Spatial Resolution } \\
\text { or Maps Scale }\end{array}$ & $\begin{array}{c}\text { Temporal } \\
\text { Resolution or } \\
\text { Date (Years) } \\
\end{array}$ & $\begin{array}{c}\text { Data Processing } \\
\text { Levels }\end{array}$ & Data Sources \\
\hline 1. & Landsat- 8 Multispectral & 30 meters & $\begin{array}{l}\text { 2016-2018 } \\
\text { (Dry and Wet } \\
\text { Seasons) }\end{array}$ & $\begin{array}{l}\text { Level 1T (Terrain } \\
\text { Corrected) }\end{array}$ & $\begin{array}{l}\text { United States Geological } \\
\text { Survey (USGS) }\end{array}$ \\
\hline 2. & Landsat-8 Panchromatic & 15 meters & $\begin{array}{l}\text { 2016-2018 } \\
\text { (Dry and Wet } \\
\text { Seasons) }\end{array}$ & $\begin{array}{l}\text { Level 1T (Terrain } \\
\text { Corrected) }\end{array}$ & $\begin{array}{l}\text { United States Geological } \\
\text { Survey (USGS) }\end{array}$ \\
\hline 3. & Sentinel-2A & 10 meters & $\begin{array}{l}2017-2018 \\
\text { (Dry and Wet } \\
\text { Seasons) }\end{array}$ & Orthorectification & $\begin{array}{l}\text { European Space Agency } \\
\text { (ESA) }\end{array}$ \\
\hline 4. & SPOT $6 / 7$ & 6 meters & $\begin{array}{c}\text { 2016-2018 } \\
\text { (Dry and Wet } \\
\text { Seasons) }\end{array}$ & Orthorectification & $\begin{array}{l}\text { Indonesian National } \\
\text { Institute of Aeronautics } \\
\text { and Space (LAPAN) }\end{array}$ \\
\hline 5. & DEMNAS & 8 meters & 2018 & Terrain Corrected & $\begin{array}{l}\text { Geospatial Information } \\
\text { Agency (BIG) }\end{array}$ \\
\hline 6. & $\begin{array}{ll}\text { Indonesian } & \text { Topographic } \\
\text { (RBI) Map } & \\
\end{array}$ & $1: 50.000$ & 2017 & - & $\begin{array}{l}\text { Geospatial Information } \\
\text { Agency (BIG) }\end{array}$ \\
\hline 7. & Geological Map & $1: 250.000$ & $1992-1996$ & - & $\begin{array}{ll}\text { Center for } & \text { Geological } \\
\text { Survey (PSG) } & \end{array}$ \\
\hline 8. & Land System Map & $1: 250.000$ & 2014 & - & $\begin{array}{l}\text { Geospatial Information } \\
\text { Agency (BIG) }\end{array}$ \\
\hline 9. & $\begin{array}{l}\text { Regional } \\
\text { Map }\end{array}$ & $\begin{array}{l}1: 100.000-1: \\
250.000\end{array}$ & $2016-2018$ & - & $\begin{array}{l}\text { Related Ministries or } \\
\text { Institutions }\end{array}$ \\
\hline
\end{tabular}

The pan-sharpening was applied using Gram Schmidt and Principal Component methods to combine multispectral and panchromatic bands. The authors applied interpretation of land cover classes using landscape ecological approach, referred to SNI 7645-1 of 2014. Field survey aimed to build interpretation or reinterpretation keys, accuracy assessment, and collection of non-spatial data. Accuracy assessment is one of the most component in the mapping project to quantitatively compare methods and the use of information resultied from the spatial data analysis in the decisionmaking process [3]. Accuracy assessment samples were collected by delineating high-resolution imagery (SPOT 6/7) and field observation. Measurement of canopy density was conducted by taking photos using fish-eye lenses in the field to be correlated with vegetation index (NDVI). Based on this analysis, vegetation index can be converted into the percentage 
of interval canopy density classes. The development of KUGI and metadata based on KUGI standard version 4.0 were used for data exchange between users, ministries, or other technical institutions.

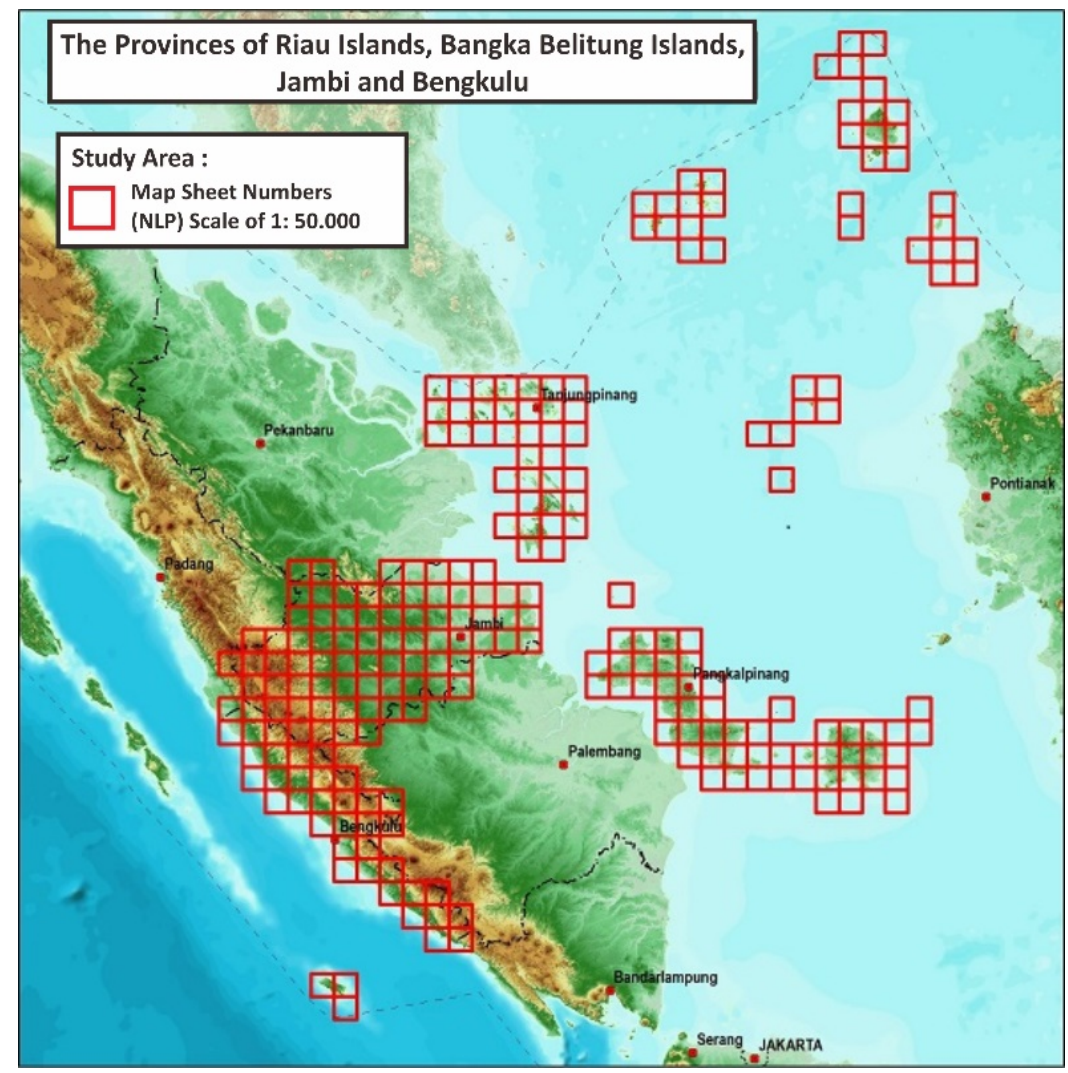

Figure 1. Map sheet numbers (NLP) in the provinces of Riau Islands, Bangka Belitung Islands, Jambi and Bengkulu covered in this study

\section{RESULTS AND DISCUSSION}

\subsection{Initial Introduction in Development of Land Cover Spatial Database}

The introduction of land cover classes contained in SNI number 7645-1 of 2014 was carried out before entering the image pre-processing stage. This process was useful to equalize the perception differences of land cover classes that would be encountered among the operators. The land cover classes were closely related to the landscape-ecological approach, where this approach was useful in providing land cover information with the physical terrain aspects [4]. The provinces of Riau Islands and Bangka Belitung Islands are in the old geomorphological stadium, where there is no addition of new parent materials at this time [5,6]. The parent material comes from volcanic activity in times ago. Practically there is only one process with three geomorphological activity (erosion, transportation, and sedimentation) both on land and on the coastal area. The geological and geomorphological conditions caused land use to be limited to land cover classes with a high level of resistant to soil acidity. Active and non-active volcanoes in Jambi and Bengkulu provinces show intermediate to old geomorphological stages $[5,6]$. The geological structure development is still going on, indicated by the earthquake process due to active faults. Rock parent material is a mixture of igneous, sedimentary, and metamorphic rocks. The geological and geomorphological conditions at this stage cause land use to be more varied, especially in plantation and forest classes.

\subsection{Image Pre-Processing}

The Indonesian Topographic Map (RBI) of 2017 was utilized as the basis of reference in the image geometric correction. Correction process was undertaken by overlaying images (Landsat-8 and Sentinel-2A) on river/coastline shapefiles. The geometric correction results showed differences in the distance between the reference image and the river/coastline shapefiles of less than 25 meters. Figure 2 showed the geometric image correction process. 


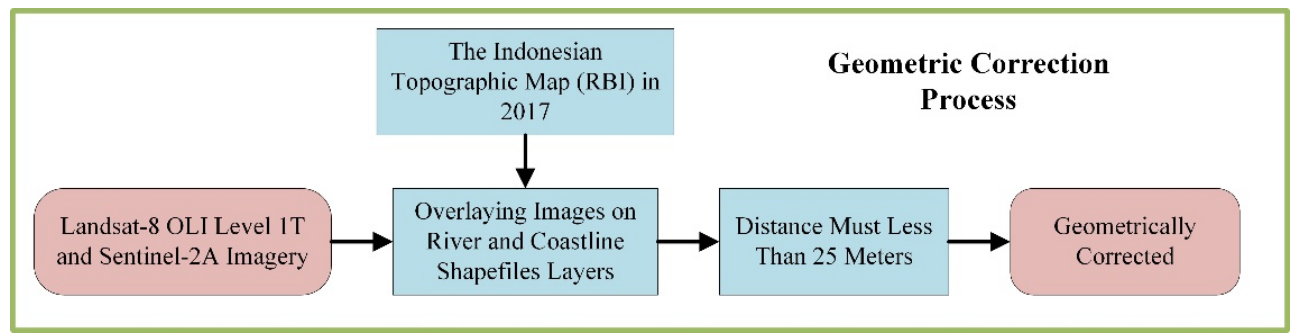

Figure 2. Geometric correction process

The next step was a relative radiometric normalization to equalize the pixel values in two or more images. Relative radiometric normalization was necessary to overcome the problems of a various number of imagery, different temporal recording, and land cover classes that overlap on each image scene (Figure 3). The reference image was chosen based on the pixel value of at-surface reflectance correction in each band of Landsat-8 imagery [7]. Then, the pixel values of the reference image were used to change the pixel value of adjoining image. This stage was carried out on all Landsat- 8 imager dataset so that the resultant Landsat- 8 mosaicked image has the relatively same pixel values on the same objects. Riau Islands province that uses Sentinel-2A imagery does not go through this relative radiometric normalization, due to its isolated scenes (see Figure 1). As a result of the overlapping land cover classes are in a small area or deep-sea water objects. So that Sentinel-2A imagery only reaches at-surface reflectance radiometric correction.

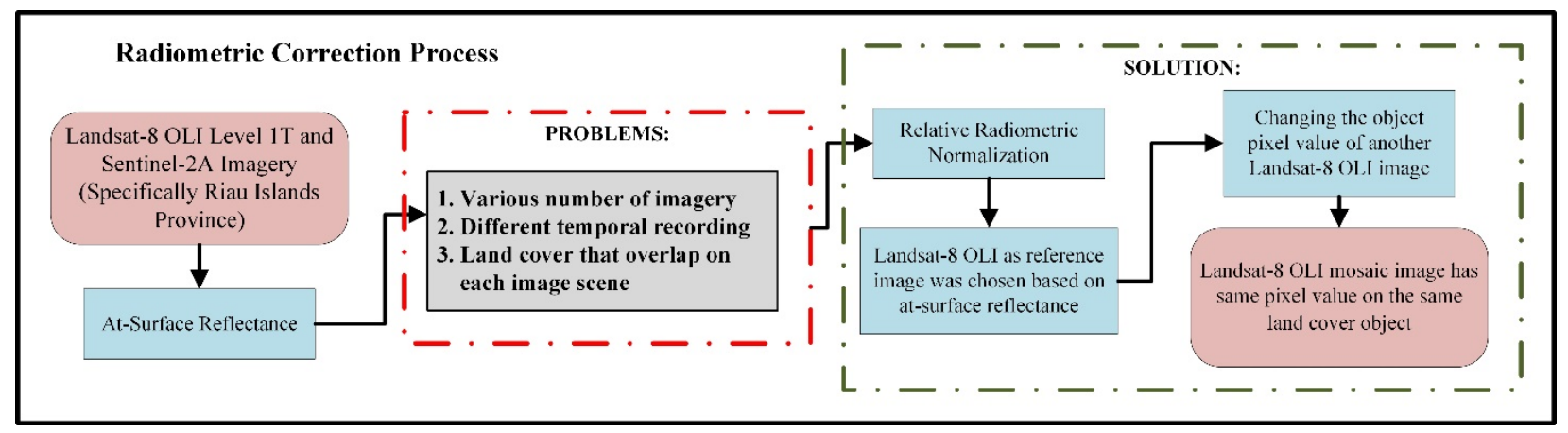

Figure 3. Radiometric correction process

\subsection{Image Processing}

The pan-sharpening image processing was useful in increasing the spatial resolution of the imagery that would be used to help the process of interpretation and delineation of land cover at a scale of 1: 50,000. Multispectral bands and panchromatic bands from Landsat-8 imagery were combined using the Gram Schmidt and Principal Component methods so that pan-sharpened Landsat- 8 has a spatial resolution of 15 meters. The result of pan-sharpened Landsat- 8 gave different appearance of land cover objects [8]. In the pan-sharpened image using the Gram Schmidt method, land cover objects could be distinguished by the visual color appearance, as compared to the results of the Principal Component method that has a gray color visual appearance. However, the Principal Component method has the advantage of differentiating the edge of the land cover class. In the Gram Schmidt method, we found pixel anomalies in other open land classes, steeper slopes, or land cover classes with pixel values close to 0 (zero).

\subsection{Interpretation Process}

Interpretation of the land cover class made use of a landscape ecological approach and referred to SNI 7645-1 of 2014. This approach was used to recognize geological and geomorphological conditions, which are the dominant factors in controlling existing land cover classes. Pan-sharpened Landsat-8 imagery are used in the delineation process, while SPOT 6/7 and Sentinel-2A images are useful in the stage of detailing and naming land cover classes [9]. The problems that arise at this stage are that cloud cover was often found in pan-sharpened Landsat-8 images, especially on islands, so that the image of SPOT 6/7 and Sentinel-2A were quite often used to overcome cloud cover problems. In one condition, the interpreter does not realize that the delineation results are not appropriate with the minimum mapping unit (MMU) standard in pan-sharpened Landsat-8 images. Level of detail (spatial resolution), texture, and shape of the land cover classes on SPOT 6/7 and Sentinel-2A imagery are better than Landsat-8 pan-sharpened, which can affect the delineation 
results. The solution to these problems was using multi-scale analysis in the delineation process, and also the supervisors team performed quality control on the results of delineation to accommodate the minimum mapping unit standard.

\subsection{Field Survey}

This activity aimed to build interpretation keys, accuracy assessment, and collecting non-spatial information [10]. Reinterpretation and accuracy assessment amount to 240 samples, distributed based on the diversity of landscapes using the stratified random sampling technique [11]. Field surveys can give a full description of the landscape in each province. In general, the provinces of Riau Islands and Bangka Belitung Islands can be classified into three landscape (geology and geomorphology) zones specifically a. Old volcanic hills eroded (central and coastal areas) shown in Figure 4a, b. Lakes, swamps, back swamps, floodplains, and alluvial plains (along rivers), c. Brackish coastal alluvial plains, inundated coastal alluvial plains, and vegetated/non-vegetated tidal averages (coastal areas) $[5,6]$.

Geological and geomorphological units are composed of felsic old volcanic rocks (granite and granodiorite). Sedimentary rocks are found especially quartz sandstones, arkose sandstones (Figure 4c), and greywacke sandstones, while metamorphic rock types consist of quartzite and schist. Red-yellow podzolic soil (Figure $4 \mathrm{~b}$ ) is dominant in these two provinces, due to the erosion of the host rock material. The geological and geomorphological conditions can be the key for interpreting the land cover class (the land cover classes must have resistance to soil acidity).
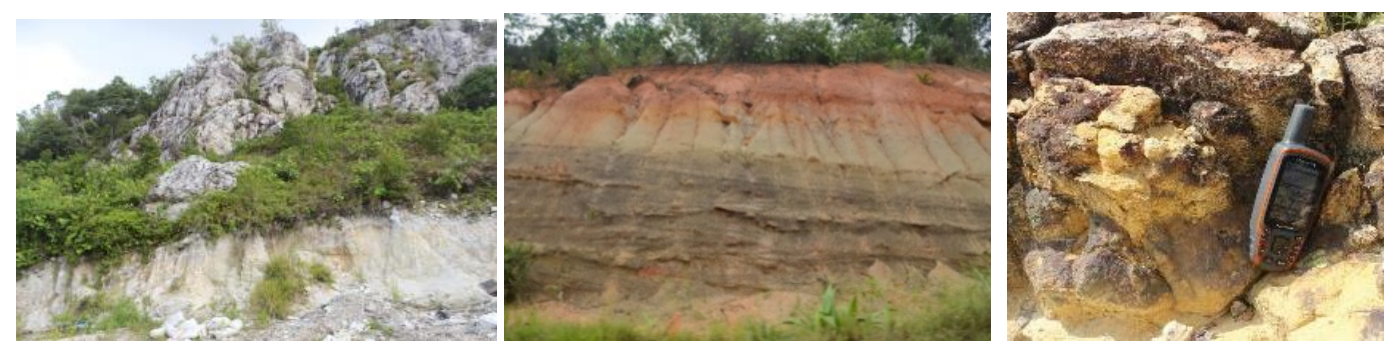

Figure 4. a. Old volcanic hills eroded moderately, b. red-yellow podzolic soils, c. arkose sandstone

Generally, Jambi and Bengkulu provinces can be classified into five landscape zones. These five zones are a. Old volcanic hills eroded (southern coastal area, old geological age), b. Crater, volcanic cone, volcanic slope, and volcanic foot slope (southern coastal area, young geological age), c. Anticlinal mountains eroded, anticlinal hills eroded, anticlinal valley, synclinal valley, hogback, and cuesta (central and southern area), d. Lakes, volcanic plains, swamps, back swamps, alluvial plains, and floodplains (northern and southern rivers), e. Brackish coastal alluvial plains, inundated coastal alluvial plains, and vegetation/non-vegetated tidal averages (northern and southern coastal area) $[5,6]$. The geology of Jambi and Bengkulu provinces are composed of felsic to mafic rock materials. The igneous rocks identified were granite and andesite, while sedimentary rocks consisted of andesite breccia, conglomerates, quartz sandstones, arkose sandstones, greywacke sandstones, and alluvium. During field survey activities, there is more variety of soil types. The types of soil found widely in these two provinces are andosols, regosols, red-yellow podzolic, latosol, and lithosols.
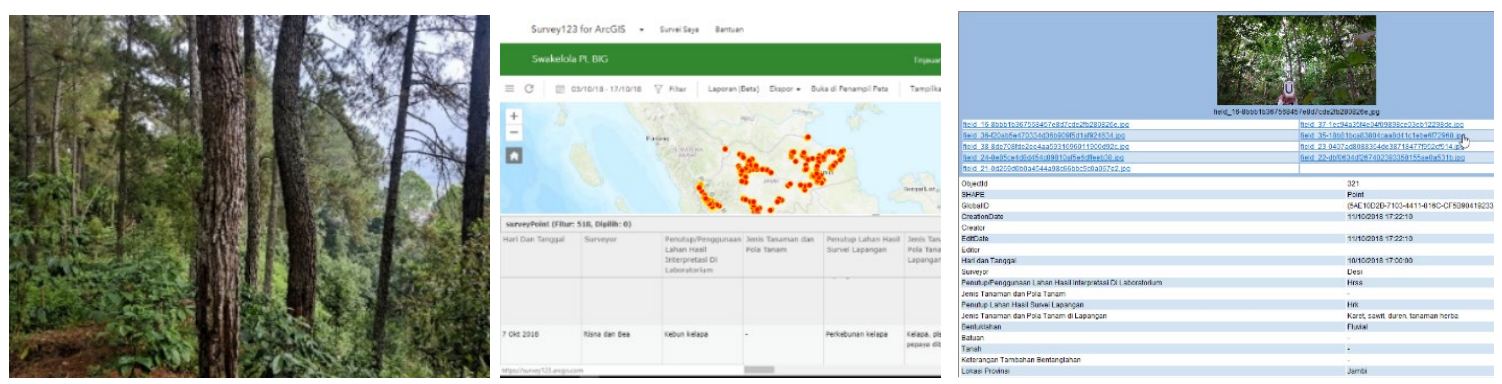

Figure 5. a. Coffee plantations with shade trees of pine trees, b. and c. sample collections display on Survey123 for ArcGIS

Manually collection of sample data was written in the checklist and then it was uploaded to the Survey123 for ArcGIS application (Figure 5b and Figure 5c). Under certain conditions, manual writing on the checklist was carried out if the field team had a problem in accessing the internet. The use of this application aimed to coordinate the field and the laboratory teams, so that the later could directly see the distribution of sample points, and could modify the point format 
of samples into area format, as the basis for accuracy assessment. Problems encountered in the survey activities were transportation in the province of Riau Islands, the terrain in Jambi and Bengkulu provinces, and oil palm plantations and rubber plantations which grew side by side in each relief class. Coffee, cocoa, tea, and rubber plantations are quite difficult to classify. Coffee plantation classes in Jambi and Bengkulu provinces were planted side by side with shade plants such as cinnamon and pine trees (Figure 5a). The plantation commodities data were required in each province to help delineate plantation classes from remote sensing imagery.

\subsection{Accuracy Assessment}

Accuracy assessment samples were collected by delineation in high-resolution imagery (SPOT 6/7) from the field and uploaded to the Survey123 for ArcGIS application for faster-collecting accuracy sample data (Figure 6). Delineation in high-resolution imagery then converted into a polygon area with an area of eight times the spatial resolution. In this case, the area specified was 240 x 240 meters. Accuracy assessment samples have two conditions, i.e., area polygons with one land cover classes and different land cover classes [11]. The use of the polygon area as an accuracy assessment was intended to make omission and commission from the land cover class known. The accuracy assessment process was carried out on land cover classification maps before and after the reinterpretation [12]. In the process, the accuracy assessments could not be carried out after the reinterpretation activities, because the classification of land cover had to go through the process of seamless merging state in each NLP and topology.

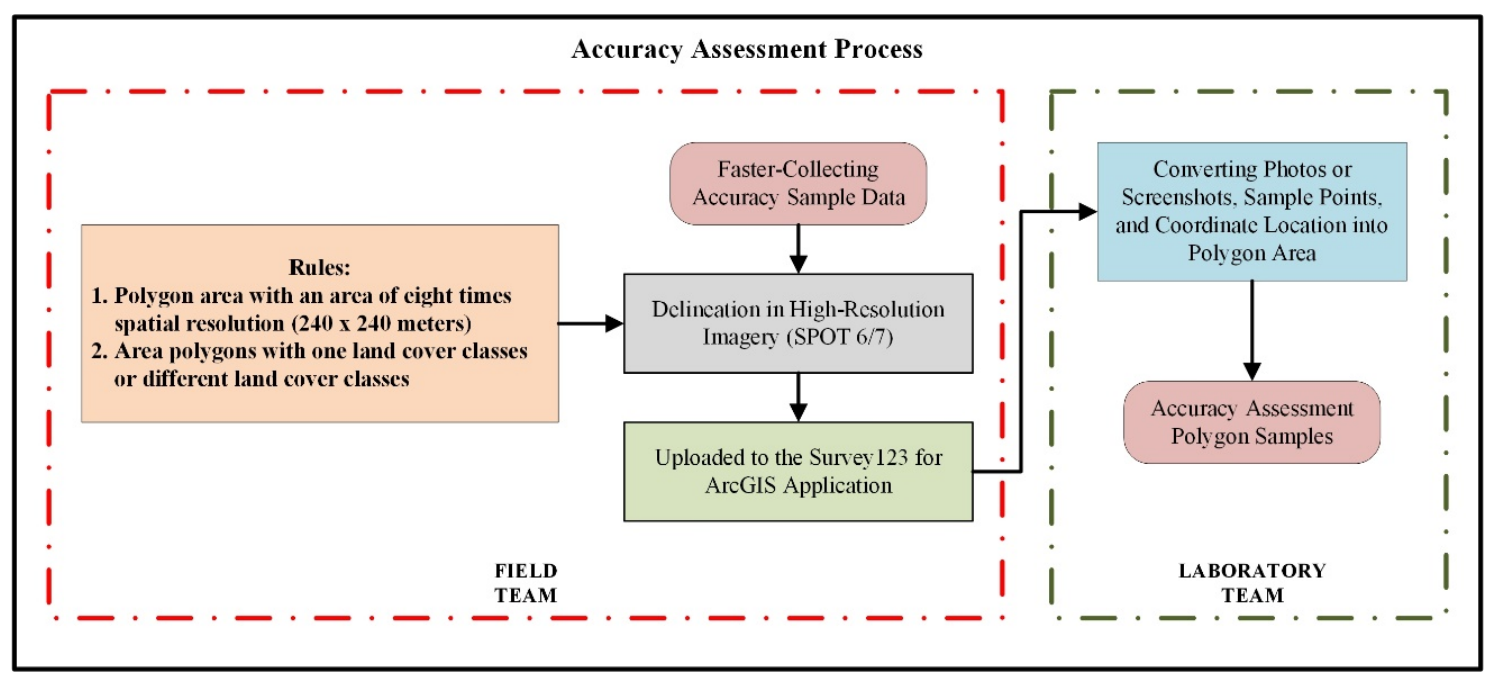

Figure 6. Accuracy assessment process

\subsection{Land Cover Matrix}

The land cover matrix showed the relative relationship of land cover classes with their landscape ecology (Table 2). This matrix was compiled based on the reinterpretation sample (landform, rocks, and soil) obtained in field survey activities. The making of a matrix was useful to equalize the perceptions of interpreters in identifying land cover classes.

Table 2. Land cover and landscape-ecological matrix

\begin{tabular}{|c|c|c|c|c|c|c|}
\hline No. & $\begin{array}{l}\text { Land Cover } \\
\text { Classes }\end{array}$ & Landform & Rocks & Soil & Matrix & $\begin{array}{c}\text { Relative } \\
\text { Relationship } \\
\text { Description }\end{array}$ \\
\hline 1. & $\begin{array}{c}\text { Extensive } \\
\text { Meadow Farm } \\
\end{array}$ & Alluvial Plains & Claystone & Alluvial & $*$ & None \\
\hline 2. & $\begin{array}{c}\text { Other Water } \\
\text { Reserves }\end{array}$ & $\begin{array}{c}\text { Inundated Coastal } \\
\text { Alluvial Plains } \\
\end{array}$ & $\begin{array}{l}\text { Claystone } \\
\text { and Sand }\end{array}$ & Alluvial and Regosol & $* *$ & Low \\
\hline 3. & $\begin{array}{c}\text { Industrial, Trade, } \\
\text { and Office } \\
\text { Buildings }\end{array}$ & Alluvial Plains & $\begin{array}{c}\text { Arkose } \\
\text { Sandstone }\end{array}$ & Red-Yellow Podzolic & $* * *$ & Moderate \\
\hline 4. & Bush & $\begin{array}{c}\text { Structural, } \\
\text { Denudational, } \\
\text { Volcanic, and } \\
\text { Fluvial }\end{array}$ & $\begin{array}{l}\text { Igneous and } \\
\text { Sedimentary }\end{array}$ & $\begin{array}{l}\text { Andosols, Latosol, } \\
\text { Lithosols, } \\
\text { Mediterranean, and } \\
\text { Alluvial }\end{array}$ & $* * *$ & High \\
\hline
\end{tabular}




\subsection{Measurement of Vegetation Canopy Density}

Measurement of canopy density was performed by taking three or five photos according to the spatial resolution (Figure 7a). An overlapping photo would look the same as measuring canopy density by using fish-eye lenses. The original photo would then go through the photo editing process in the photography software. Editing process (Figure 7b) consisted of a cropping process to remove distracting objects, brightness level adjustment to separate dark and bright objects, adding black frames around each photo, and saving a photo to 8-byte format (0-255). Calculation of the percentage of dark and bright objects was performed on the photo editing results to calculate the canopy density. The next process was using linear regression to change the Normalized Difference Vegetation Index (NDVI) value to match the measurement results in the field.
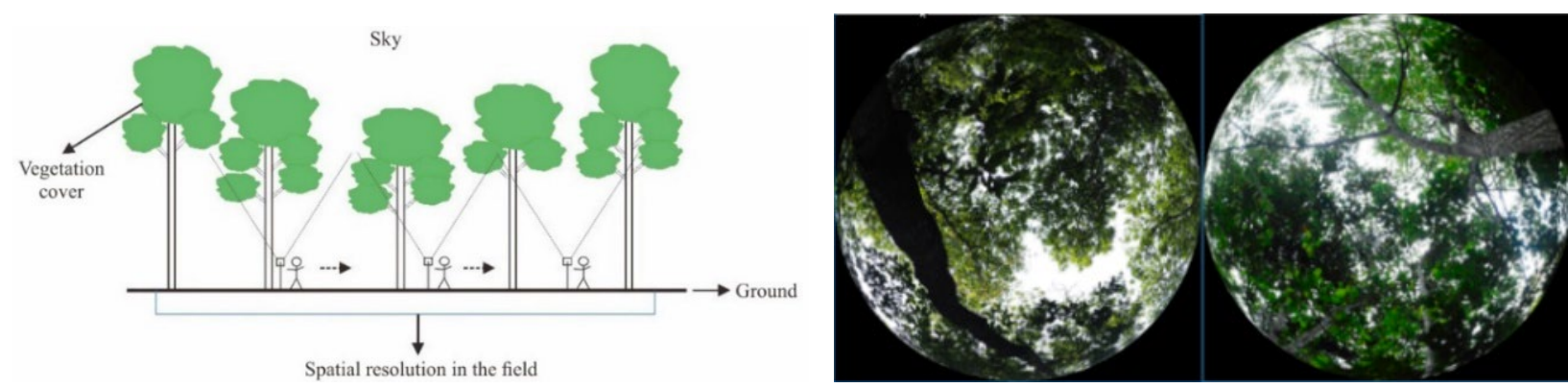

Figure 7. a. The technique of capturing photos of canopy density and b. the results of the photo editing process after a field survey.

\subsection{Quality Control}

Quality control was carried out by the supervisor team from spatial data collection to the results of land cover mapping. The initial quality control was related to the spatial, spectral, radiometric, and temporal resolution to assess the quality of spatial data, both primary and secondary data. The use of various types of spatial data with different resolutions/scale and advanced radiometric corrections (relative radiometric normalization), causes quality control must be carried out in the beginning stages of spatial data collection. Whereas, the quality control of delineation/reinterpretation was performed by checking at the delineation/reinterpretation results that are correct or incorrect with the interpretation key of land cover classes in Landsat-8 pan-sharpened, assisted with SPOT 6/7 and Sentinel-2A imagery. Common misinterpretations frequently encountered by the supervisor team were the results of delineation/reinterpretation that did not meet the minimum mapping unit standards of Landsat-8 pan-sharpened, polygons with awkward boundaries/lines, and land cover attributes that were not correct. These errors were generally caused by different interpreter's experiences.

\subsection{Seamless Merging Process}

The seamless merging process of land cover classes aimed to reach the land cover map of the Sumatra Islands at scale of 1: 50.000 (Table 3). The difference in the results of delineation of the land cover class was often found, between team A and team B who were involved in mapping land cover classes. The solution of these problems was by superimposing the delineation of the land cover with Landsat- 8 pan-sharpened as primary data. If the team still found disagreements, the next step was referring to the land cover classification scheme (SNI 7645-1 of 2014) and the terms of references (KAK) as a project document for mapping land cover classes. The landscape ecological approach was also utilized in this process to identify correct or incorrect land cover classes. In some situations, the seamless merging process required high-resolution imagery (SPOT 6/7 and Sentinel-2A) or the one with the latest recording years [13]. Figure 8 showed the seamless merging process of land cover classes.

Table 3. Example of a row of the seamless merging process

\begin{tabular}{ll} 
Before the Seamless Merging Process After the Seamless Merging Process & \multicolumn{1}{c}{ Description } \\
\hline & $\begin{array}{l}\text { a. } \\
\text { Team A : Adding polygon boundaries } \\
\text { of Village Settlement Building } \\
\text { (Associated with Yard Vegetation) } \\
\text { classes in West Sumatra province (red } \\
\text { line). }\end{array}$ \\
$\begin{array}{l}\text { beam B : Adding polygon boundaries } \\
\text { of Rubber Plantation classes in Jambi } \\
\text { province (yellow line). }\end{array}$
\end{tabular}




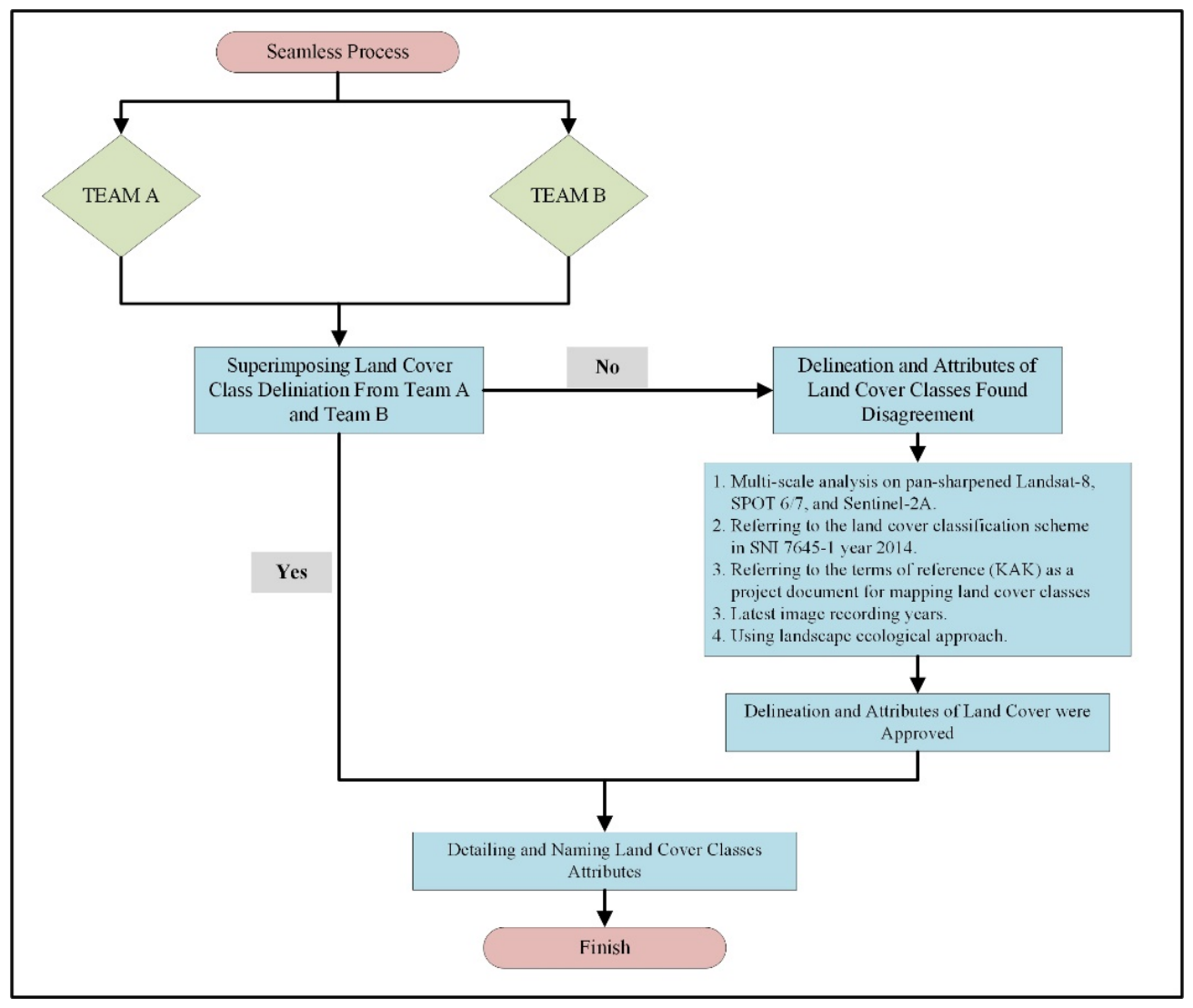

Figure 8. Seamless merging process of land cover classes

Boundaries and attributes seamless merging processing of the land cover classes were carried out in the provinces of Jambi and Bengkulu. This provinces share borders with the provinces of West Sumatra, South Sumatra, and Riau. Riau Islands and Bangka Belitung Islands provinces do not go through this seamless merging process because their borders are located in the deep-sea waters.

\subsection{Development of Indonesian Geographic Element Catalog (KUGI) and Metadata Standard}

The development of KUGI and metadata based on KUGI standard version 4.0, where the land cover classes are assigned an inventories number. Some land cover classes such as other water bodies, shallow sea waters, deep-sea waters, and other stretches of rock/sand have not entered this standard. The solution to this problem was the need for further studies for KUGI numbering and metadata so that the land cover classes that have not entered KUGI standard have an inventories number. This study needs to be carried out by the data owner of the land cover map because it involves the ease of users and the data exchange between ministries or institutions. It was possible in other provinces the land cover classes do not have inventories number and metadata from KUGI standard version 4.0.

\subsection{Land Cover Map Layout}

Classification of the land cover classes were then illustrated through symbolization for the map layout that has been standardized based on SNI 7645-1 of 2014. The land cover class symbols can be in the shape of polygon colors, polygon colors with shading lines, and polygon colors with dot points. The various land cover classes and map output with different scales led to an adjustment of symbol design to the provincial and the district level map layouts. Adjustments occurred by changing the outline symbol size of the polygon area, line, and point. The sub transportation title in the legend was still not right because it contains road class information (Figure 9c). Furthermore, some land cover classes, for example, "sand, soil, and rock (sirtu) excavation" and "other natural/semi-natural vegetation coverage (not specified)" have different polygon size in each province. Under certain conditions, the land cover classes have a small polygon size with a none bright color symbol, so the land cover classes are not visible in the map layout (Figure 9a and Figure 9b). 
Further studies are needed to solve problems about color symbols, symbol sizes, and land cover class legends in the map layout.

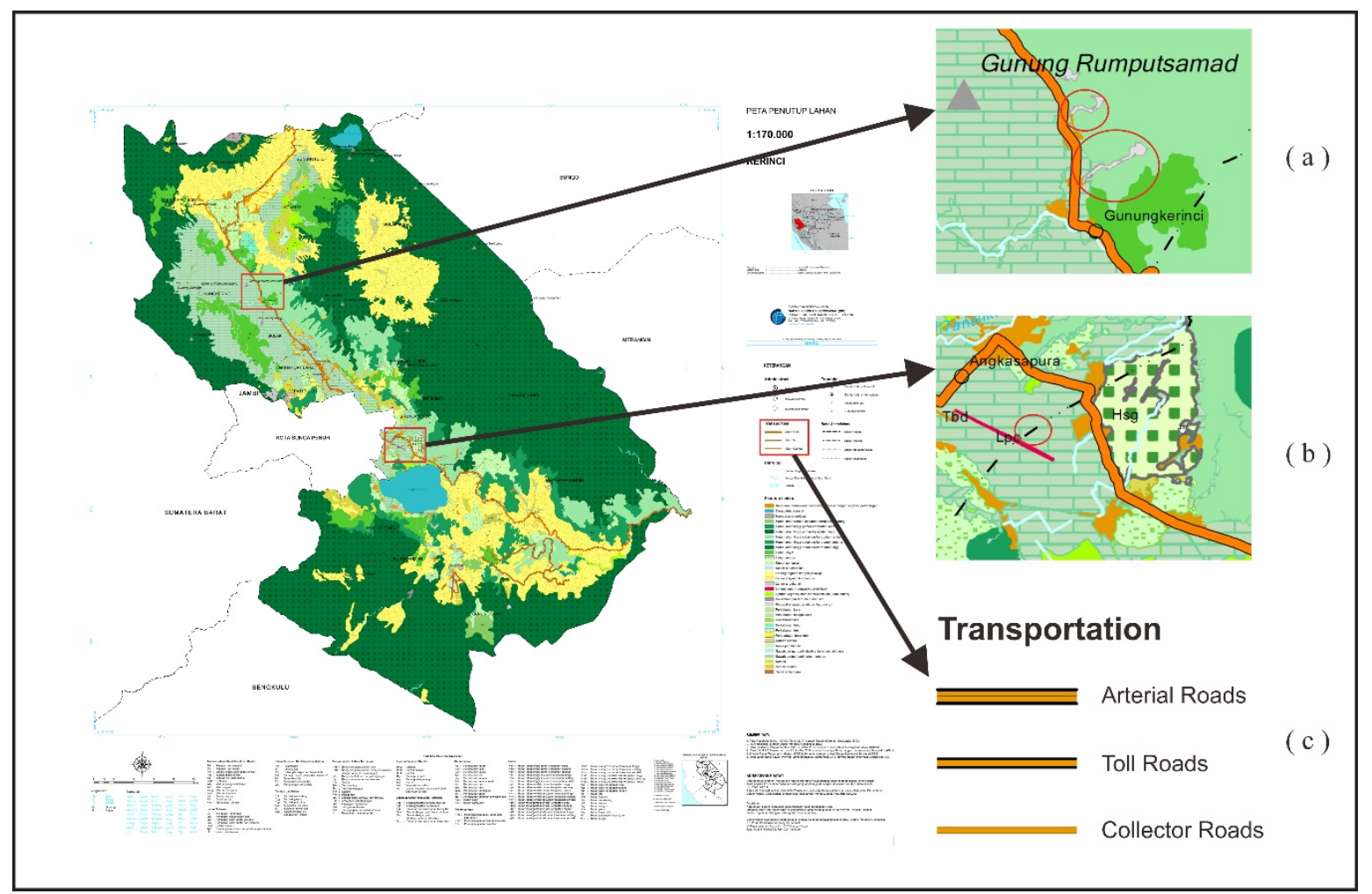

Figure 9. a and b. Examples of land cover of map layout: the land cover classes with small sizes and color symbols that are not visible, c. sub transportation titles that are not corrected.

\section{CONCLUSIONS}

From the development of land cover spatial database in the provinces of Riau Islands, Bangka Belitung Islands, Jambi, and Bengkulu, there are conclusions and suggestions, namely:

1. There were land cover classes that have not been classified in SNI 7645-1 of 2014 but are found widely in the study area. These classes were, inland swamp vegetation, swamp/peatland areas with bush or shrub (not vegetated), other open lands of abandoned mines areas (not utilized), abandoned puddle/pond area of mines, pepper plantation, and clove plantation. The revision of SNI 7645-1 of 2014, in the future, needs to consider this land cover classes.

2. The categorization on the map was the result of the implementation of the SNI 7645-1 of 2014, which is very detailed. However, not all land cover classes could be converted or translated easily into one of the layers in the Indonesian Topographic (RBI) map. On the other hand, land cover mapping specifically, used to create one of the RBI map layers seen as inefficient. Therefore, a conversion or translation system was needed to bridge the gap between the two.

3. Future studies are needed to solve KUGI development, metadata, and map layout problems. Some of the specific land cover classes did not have the KUGI inventories number and the land cover class symbol that was not appropriate. 


\section{REFERENCES}

[1] Jensen, J. R.,[Introductory Digital Image Processing - A Remote Sensing Perspective], N.J.: Prentice Hall, Englewood Cliffs, 3rd Edition (2005).

[2] Lillesand, T.M., Kiefer, R.W., Chipman, J.W., [Remote Sensing and Image Interpretation], John Wiley and Sons, New York, 5th Edition (2014).

[3] Congalton, R.G. "Accuracy assessment and validation of remotely sensed and other spatial information," Papers, United States and Canada (2001).

[4] Danoedoro, P. [Land-use Information from the Satellite Imagery: Versatility and Contents for Local Physical Planning], Lambert Academic Publishing, Sarsbrucken (2009).

[5] Van Zuidam, R.A., and Van Zuidam-Cancelado, F.I., [Terrain Analysis and Classification using Aerial Photographs A Geomorphological Approach], ITC Textbook of Photo-Interpretation, Enschede, Volume VII-Chapter 6 (1979).

[6] Suharsono, P. [Identifikasi Bentuklahan dan Interpretasi Citra untuk Geomorfologi], PUSPICS and the National Survey and Mapping Coordinating Board (BAKOSURTANAL), Yogyakarta (1999).

[7] Danoedoro, P. [Pengantar Penginderaan Jauh Digital], Penerbit Andi, Yogyakarta (2012).

[8] Gao, J., [Digital Analysis of Remotely Sensed Imagery. San Fransisco: McGrawHill. Giri, C. (2012) (ed). Remote Sensing of Land-use and Land-cover. Principles and Applications], CRC Press, New York (2010).

[9] Danoedoro, P., McDonald, G., and Phinn, S. "Developing a versatile land-use information system based on satellite imagery for local planning in Indonesia. Phase I: establishment of classification scheme," Proc. GISDECO (2004).

[10] McCoy, R., [Field Methods in Remote Sensing], The Guilford Press, New York (2005).

[11] Danoedoro, P. "Pengaruh jumlah dan metode pengambilan titik sampel penguji terhadap tingkat akurasi klasifikasi citra digital penginderaan jauh," Papers, Yogyakarta, October. 25-26 (2015).

[12] Congalton, R.G., and Green, K.,[Assessing the Accuracy of Remotely Sensed Data. Principles and Practices], CRC Press, New York, 2nd Edition (2009).

[13] Danoedoro, P., "Extracting land-use information related to socio-economic function from Quickbird imagery: a case study of Semarang area, Indonesia," Paper presented at the MapAsia 2006 Conference, Bangkok (2006). 